\title{
Replacement of Gas Metal Arc Welding by Friction Welding for Joining Tubes in the Hydraulic Cylinders Industry
}

\author{
Jeferson André Sbalchiero ${ }^{a}{ }^{\oplus}$, Douglas Martinazzi $i^{b}{ }^{\circledR}$, Guilherme Vieira Braga Lemos ${ }^{b, c *}$, $^{\text {, }}$ \\ Afonso Reguly ${ }^{b}$, Fabiano Dornelles Ramos ${ }^{d}(\mathbb{0}$ \\ ${ }^{a}$ Parker Hannifin Corporation, Divisão Hidráulica, Cachoeirinha, RS, Brasil. \\ ${ }^{b}$ Laboratório de Metalurgia Física (LAMEF), Programa de Pós-Graduação em Engenharia de Minas, \\ Metalúrgica e de Materiais (PPGE3M), Universidade Federal do Rio Grande do Sul (UFRGS), \\ Porto Alegre, RS, Brasil. \\ ${ }^{c}$ Universidade Regional Integrada (URI), Erechim, RS, Brasil. \\ ${ }^{d}$ Instituto Federal do Rio Grande do Sul (IFRS), Caxias do Sul, RS, Brasil.
}

Received: January 05, 2018; Revised: March 07, 2018; Accepted: April 15, 2018

\begin{abstract}
Friction welding is a solid state technology which has been used worldwide. Potential advantages may be recognized as reducing welding project costs, weld weight, environmental impact and to promote enhanced mechanical properties. However, traditional welding methods are still a common practice in many engineering areas. In this sense, this work aims to present the technical advantages for replacing gas metal arc welding (GMAW) by friction welding for joining hydraulic cylinder tubes. The feasibility of friction welding was demonstrated by microstructural analysis, mechanical properties and hydrostatic pressure testing. The results showed enhanced mechanical properties for the friction welded tubes. In addition, macro and microstructural features presented distinguishable process characteristics which reflect in different microhardness values. The friction weld exhibited a better behavior in bending as well as hydrostatic tests.
\end{abstract}

Keywords: Gas Metal Arc Welding, Friction Welding, Microstructure, Mechanical properties.

\section{Introduction}

SAE 1026 and SAE 1030 grades represent hypoeutectic steels commonly obtained by hot rolling processes. These materials are often used in the industry ${ }^{1}$ being applied as drive shafts, connecting rods, spindles, and other automotive parts. They are also the base material for tubes of hydraulic cylinders, in parts of tractors and agricultural machinery. From the microstructure point of view, these low carbon steels normally achieve proeutectoid ferrite and pearlite structure at room temperature, but it strongly depends on the heat treatment as well as the cooling rates adopted. These materials are commonly selected due to their wear resistance, and are often heat treated to meet the strength requirements ${ }^{2}$.

Welding and joining processes are common practices in hydraulic cylinders companies. Components are usually joined by conventional arc welding processes where the fusion and solidification occurs. In this scenario, the most widespread welding methods are Shielded Metal Arc Welding (SMAW), GMAW and GTAW (Gas-Shielded Tungsten Arc Welding). However, traditional fusion welding techniques can lead to several problems such as hydrogen embrittlement, solidification cracks, and porosity ${ }^{3-6}$. In addition, fusion welding may also be related to unhealthy environments and exposure to radiation ${ }^{7}$. Friction based processing is characterized by solid state joining methods that can weld several materials both ferrous based alloys ${ }^{8}$ and non-ferrous alloys such as titanium 9 and nickel based alloys ${ }^{10,11}$. As potential advantages over conventional welding could be the possibility of achieving an excellent joint quality, joining of dissimilar materials, cost savings and increased mechanical properties ${ }^{12,13,14}$. Finally, it can be indicated that the friction welded parts can be cooled rapidly than fusion welds, since lower process temperatures are normally reached.

Modern non fusion welding methods are important because in applying them, many problems related to fusion and/or solidification can be avoided. On these terms, the possibility of substituting GMAW process by friction welding is essential. Hence, this work aims to evaluate the technical advantages in replacing fusion welding by friction welding for joining tubes in the hydraulic industry.

\section{Materials and Methods}

A tube of SAE 1026 seamless steel with an outside diameter of $76.2 \mathrm{~mm}$, thickness of $12.6 \mathrm{~mm}$ and length of $172 \mathrm{~mm}$ was selected. The tubes were manufactured by the Mannesmann process. The bottom was fabricated from a bar made of SAE 1030. The welding wire for GMAW was an ER70S-6 with $1.2 \mathrm{~mm}$ in diameter. The chemical composition of the main elements of these components is shown in Table 1. 
Table 1. Chemical composition of welded parts (weight \%).

\begin{tabular}{lccccccccccc}
\hline Part & $\mathrm{C}$ & $\mathrm{Si}$ & $\mathrm{Mn}$ & $\mathrm{P}$ & $\mathrm{S}$ & $\mathrm{Cr}$ & $\mathrm{Mo}$ & $\mathrm{Ni}$ & $\mathrm{Cu}$ & $\mathrm{Fe}$ \\
\hline Tube & 0,26 & 0,27 & 0,80 & 0,018 & 0,011 & $<0,022$ & $<0,005$ & $<0,005$ & 0,028 & 98,6 \\
Bottom & 0,23 & 0,14 & 0,48 & 0,021 & 0,008 & 0,005 & $<0,005$ & $<0,005$ & 0,034 & 99,1 \\
\hline
\end{tabular}

The joining processes were carried out considering two parts named as bottom and tube (indicated in Figure 1a)). In this sense, Figure 1b) shows the general assembly of the workpieces used (either for GMAW or friction technology). The schematic drawing shows the parts required to perform the friction weld. In this case, it was indispensable to machine a cavity to hide the flash.

a)
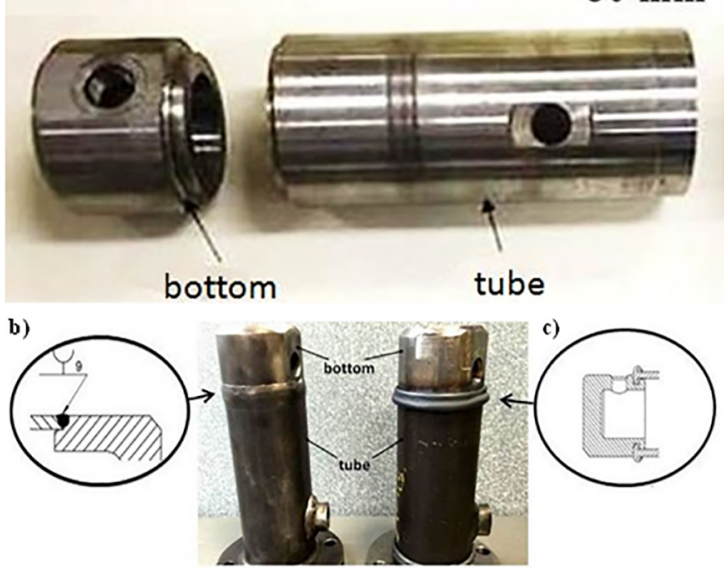

Figure 1. a) Workpieces (parts) b) GMAW joint c) friction weld

In the case of GMAW process, two Jetline machines were used for joining. In this context, one equipped with circumferential welding head positioned on the horizontal line and the other at $45^{\circ}$ with two Miller Deltaweld 652 (650A and $10-44 \mathrm{~V})$ welding parts. Both machines are semiautomatic and the procedure for positioning the torch was done manually.

Friction welding was performed using a Thompson machine of 125 tons. This machine is equipped with an electric motor that has an output of $165 \mathrm{~kW}$ and a rotational speed up to $1775 \mathrm{rpm}$. The main shaft is driven by a V-belt drive with disk braking. It should be noted that an additional recipient for welding flash was necessary (Figure 1c)).

The samples were prepared by standard metallography procedures using abrasive papers and diamond polishing solution. Afterwards, the samples were etched by Nital solution $2 \%$ in order to reveal the macro and microstructural features observed by optical microscopy (OM).

The microhardness evaluation considered the joint cross section. These analysis was performed by using an Instron equipment based on the standard ASTM E384 ${ }^{15}$, in which the load applied was $0,3 \mathrm{kgf}$ for 30 seconds.
Tensile tests were held on an Instron machine with nominal capacity of $200 \mathrm{kN}$, according to ASTM E8/8M ${ }^{16}$. The fractured tensile samples were analyzed by scanning electron microscopy (SEM) and stereoscope. Complementary, the samples for bending tests were designed considering the DIN EN ISO $7438{ }^{17}$ as it is displayed in Figure 2. These bending tests were performed in the root position. Finally, the weld bead was positioned in the center.

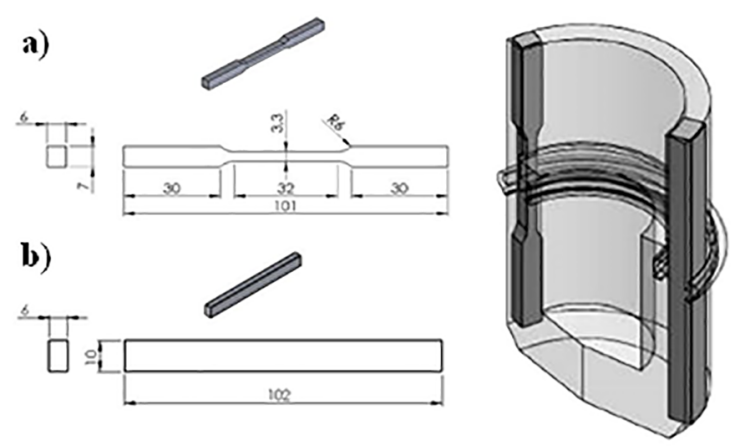

Figure 2. Dimensions of the specimens (a) tensile test e (b) bending test

The hydrostatic testing aimed to submit the welded joints (GMAW and friction) to the maximum working pressure tested in the hydraulic cylinder. In this case, the joints were subjected to pressures up to 1400 bar or the maximum supported. The hydrostatic test was done according to NFPA-T2.6.1 R2-2000 ${ }^{18}$, which indicates that when a sample supports pressure of 200 bar (minimum), it is considered approved.

\section{Results}

\subsection{Macrograph}

The macrostructure of the GMAW weld is presented in Figure 3. As can be seen, different regions were identified: the weld metal (WM - region 1), heat affected zone (HAZ - regions 2, 3 and 4), base material tube (BM - region 5), and the base material bottom (region 6). The base material areas were not affected by the welding process. Moreover, the HAZ macrostructure occurs due to the additional thermal effect coming from the welding process. Still, it is well known that HAZ has coarser microstructure in comparison to the base material.

The macrostructural features of friction welds are shown in Figure 4. The characteristic of solid state process nature is evident. In other words, no solidification occurred. In addition, different zones can be seen: the mixing zone (MZ), thermo mechanically affected zone (TMAZ), heat affected 


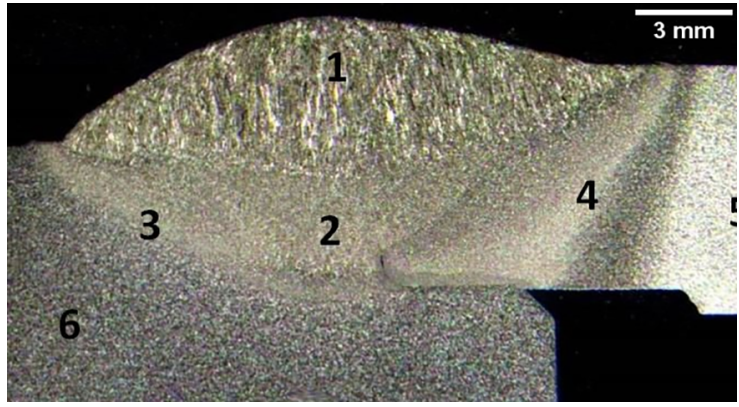

Figure 3. GMAW joint cross section macrograph

zone (HAZ). The base material bottom (region 1), as well as the tube parent metal (region 7) were also identified. It was also possible to observe the flash formed which was encapsulated in the additional recipient. Therefore, the excess of plasticized material was responsible for the flash formation. The thermo mechanical characteristic of the friction weld can also be recognized due to the transition zone (regions 3 and 5). Moreover, the HAZ extension was found to be of approximately $0,7 \mathrm{~mm}$ (either for the bottom or tube - regions 2 and 6 , respectively). This extension appeared to be lower than that achieved by the GMAW joint.

\subsection{Weld microstructure}

As presented above, the main weld regions were initially identified by the macrographs. In addition, as illustrated in (Figure 5a), microstructural features of the bottom base material were recognized, where ferrite and pearlite structures were revealed. Moreover, the microstructure of the base material tube (Figure 5b)) was found to be also ferrite and pearlite, but there was a visible microstructural alignment that came from the manufacturing processes such as metal forming rolling process.

Based on the macrostructure presented in Figure 3, three important regions were selected to detailed microstructural analysis. Thus, Figure 6a) shows the HAZ bottom microstructure. In this region, a reduction in the ferritic grain size is due to the

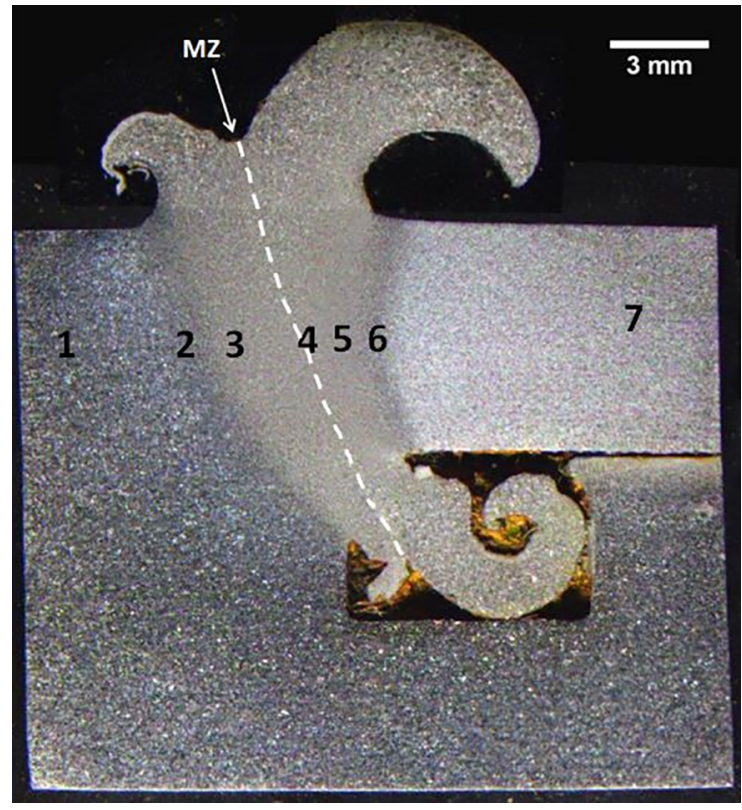

Figure 4. Friction weld cross section macrograph

higher temperature. Thus, the microstructure is composed of pearlite and grain boundary ferrite. The WM microstructure of a low carbon low alloy metal (Figure 6b)) is a result of the columnar epitaxial growth as well as the influence of the previous austenite state ${ }^{19}$. As a result, this microstructure is formed by acicular ferrite, Widmanstätten ferrite, ferrite in the grain boundary, carbide aggregate and pearlite. Finally, Figure 6c) presents the HAZ tube microstructure which also presents a reduction in the ferritic grain size due to heat imposed by the GMAW process. This later microstructure is composed by pearlite, polygonal and Widmanstätenn ferrite.

The friction weld microstructure is shown in Figure 7. It displays the friction weld regions named as the TMAZ bottom, MZ and TMAZ tube. In this context, Figure $7 \mathrm{a}$ shows the bottom TMAZ microstructure which is composed by pearlite, grain boundary allotriomorphic ferrite and
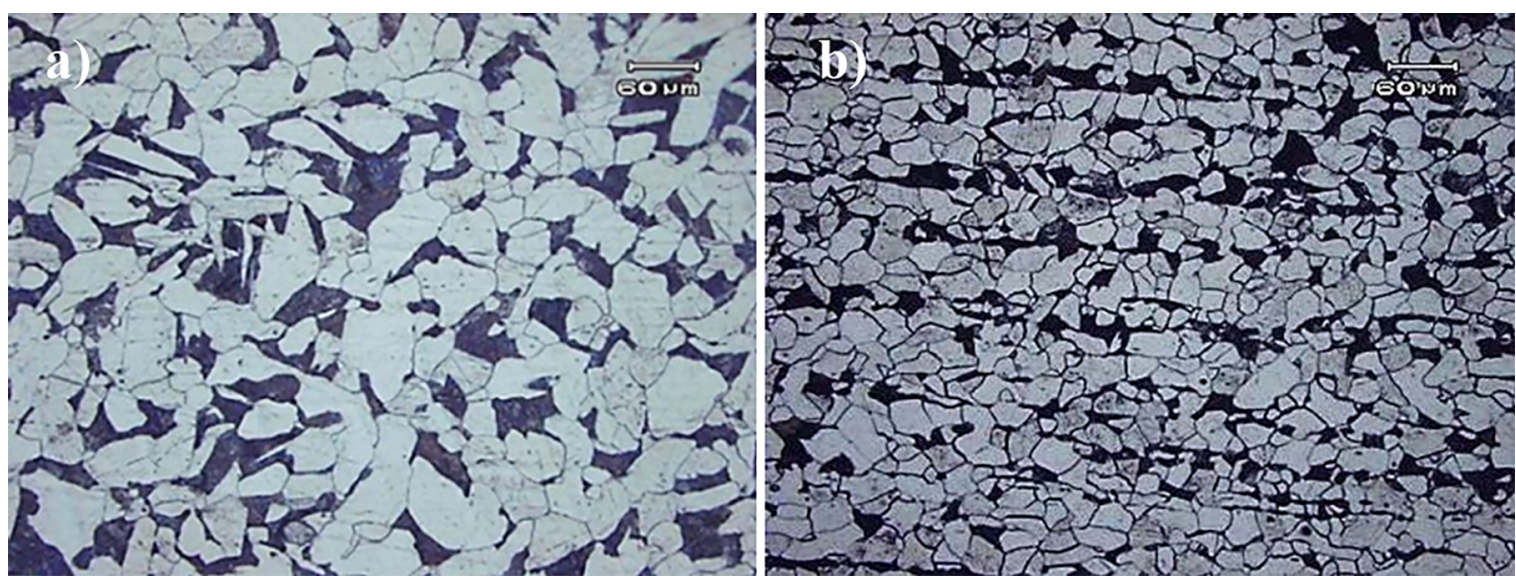

Figure 5. Base material: (a) bottom (b) tube 

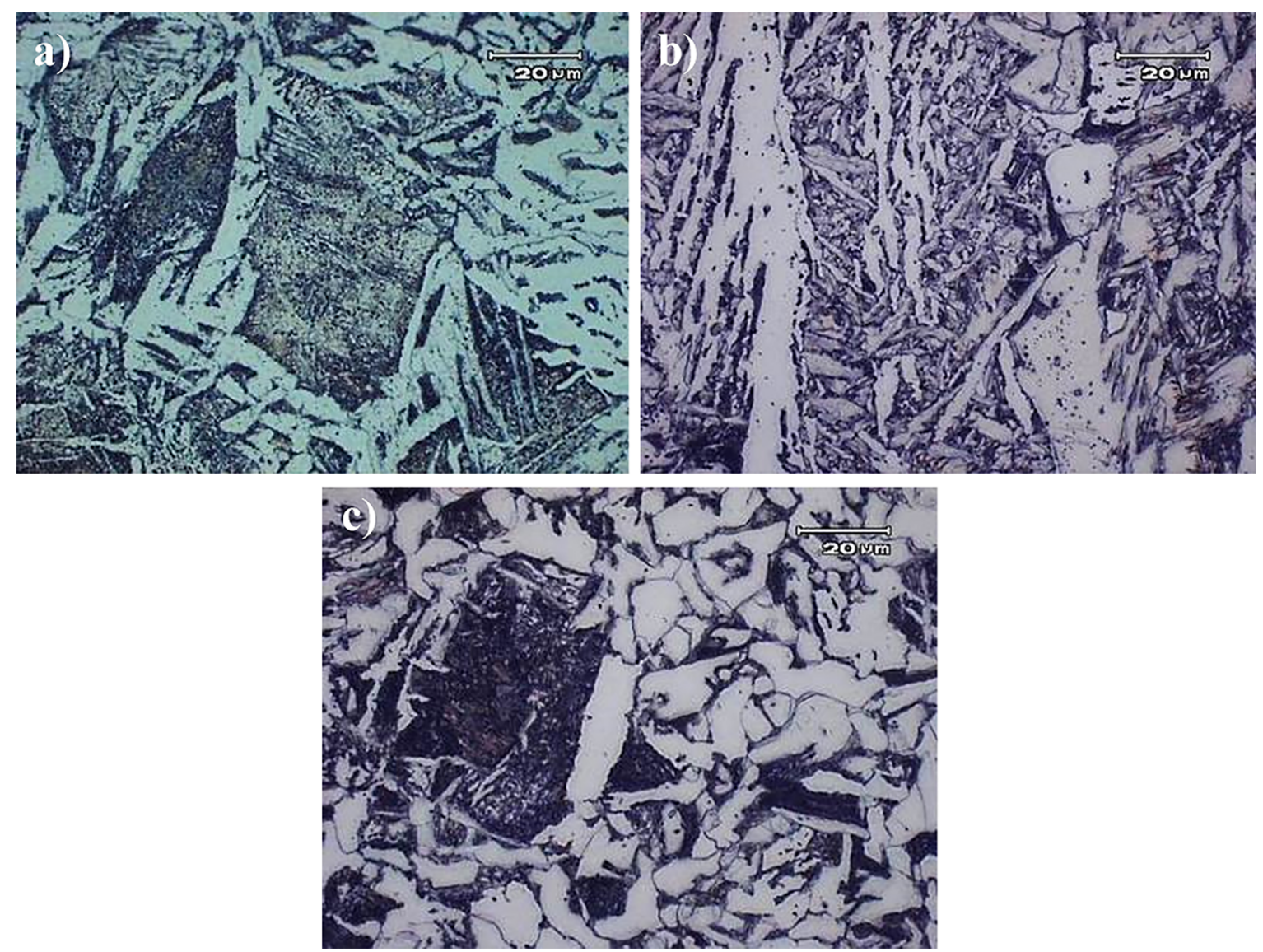

Figure 6. GMAW joint microstructure: a) HAZ bottom, b) WM, c) HAZ tube

Widmanstättenn ${ }^{19}$. In the direction of the weld centerline, as can be seen in Figure 7b), the MZ microstructure is presented. This microstructure is basically formed by acicular ferrite and pearlite. On the other side, Figure 7c) shows the TMAZ tube microstructure which was composed by coarse pearlite, grain boundary and Widmanstättenn ferrite. Acicular ferrite is a desirable microstructural feature due to its relation with good toughness; however, grain boundary ferrite can adversely affect this property ${ }^{8}$. Still, the acicular ferrite with finer microstructure would prevent the initiation and propagation of cracks ${ }^{20}$.

\subsection{Microhardness}

Microhardness profiles were performed for both joints. Figure 8 shows the GMAW hardness measurements, where the main weld regions reveled by metallography were observed. The bottom base material achieved $150 \mathrm{HV}$ which was approximately the same value found in the tube parent metal. In the direction of the weld centerline, considering the HAZ region, there was a considerably enhancement of hardness $(230 \mathrm{HV})$ due to harder microstructures formed. In view of WM, the hardness is decreased to values similar to those of the base material. Still, in this WM zone, it seems that the ferritic pearlite grain growth directly affected the microhardness values. In general, these microhardness results along the measurements were more heterogeneous.

Figure 9 shows the friction weld microhardness profile. As can be noted, there was a small increase in the HAZ microhardness (regions of the bottom and tube). This enhanced value was around $220 \mathrm{HV}$. In the TMAZ regions, a decreasing hardness was observed. For the HAZ tube region, the hardness was increased up to $240 \mathrm{HV}$. This has relation with grain refinement and/or harder phases present in this region. Although maximum hardness values were observed here, it can be assumed that the microhardness profile is more homogeneous.

\subsection{Tensile testing and its fracture}

Figure 10 shows the tensile testing results for the different welds evaluated. Although fusion weld (GMAW) reached the highest ultimate tensile strength (UTS) value, this joint presented the largest variation in the elongation. This fact can be attributed to the particular weld microstructural heterogeneity. On the other hand, tensile tests performed on the friction welds showed similar elongation and have, therefore, certain degree of homogeneity. As an average, the friction weld UTS was superior and this indicates a process stability. Finally, these results can be observed in Table 2 . 

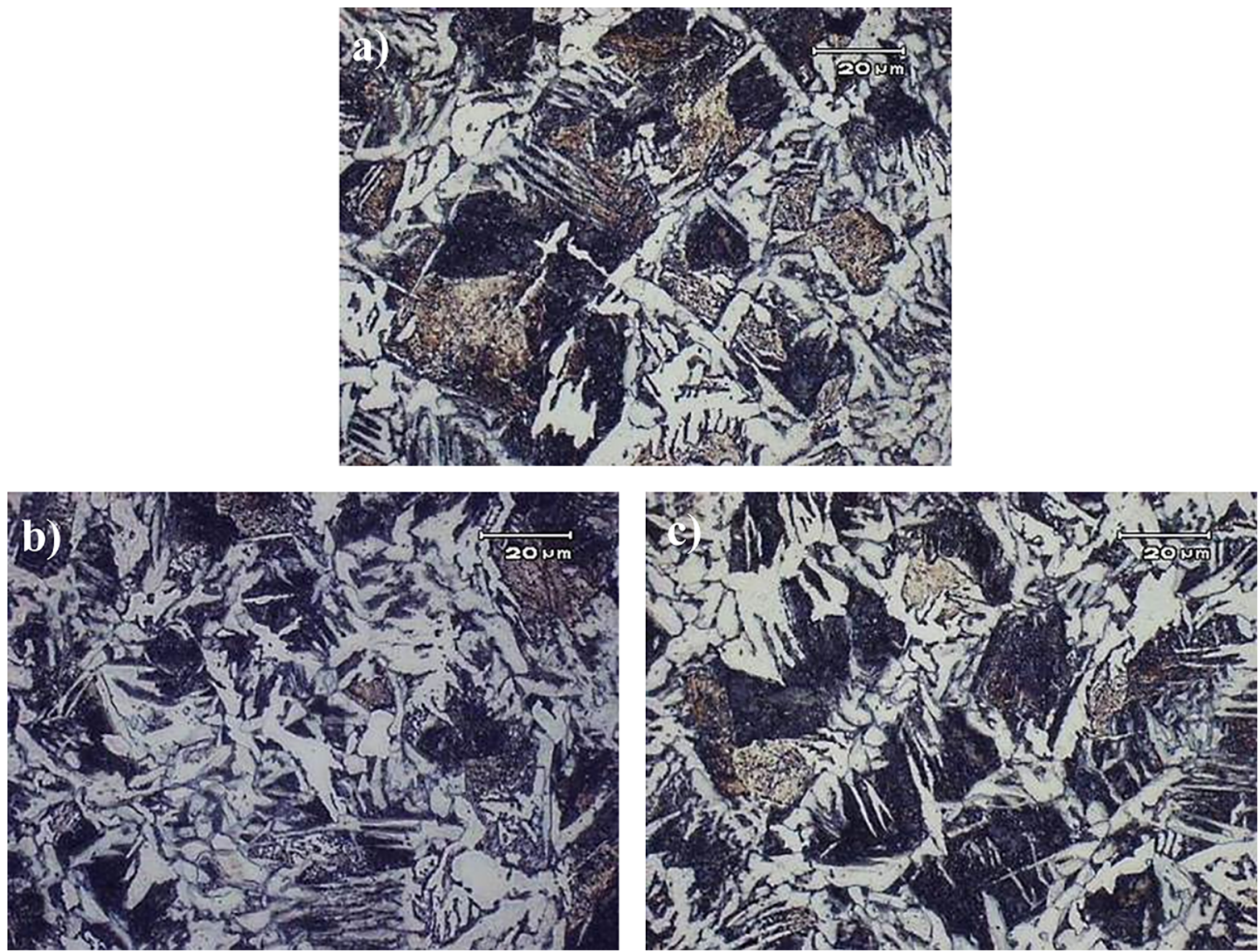

Figure 7. Friction weld microstructure: a) TMAZ bottom, b) MZ c) TMAZ tube

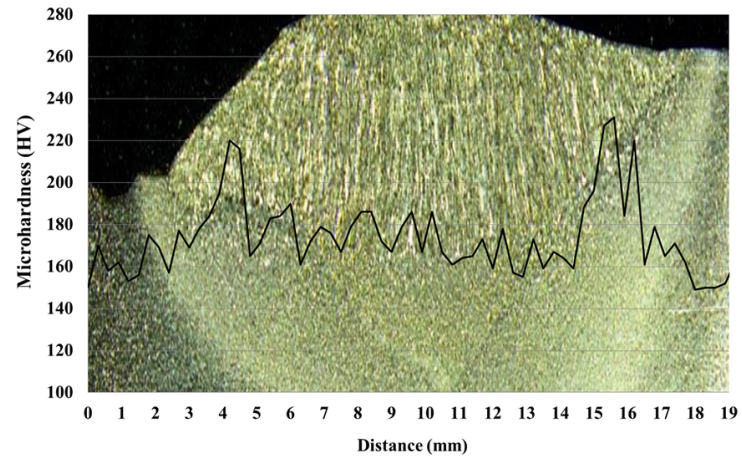

Figure 8. GMAW joint microhadness profile

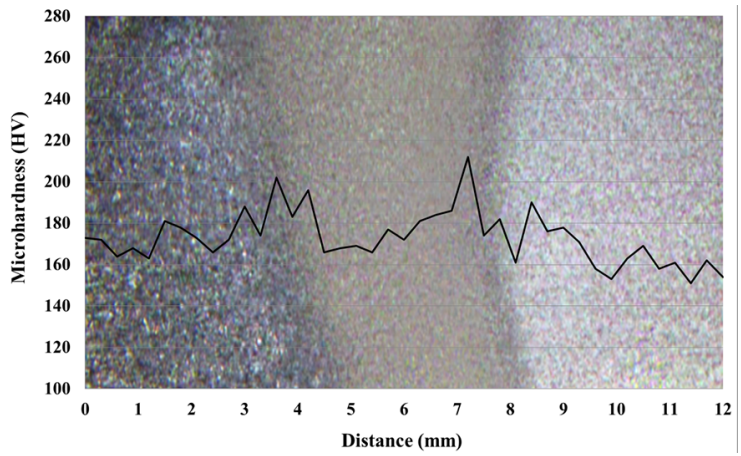

Figure 9. Friction weld microhardness profile
The fractures of the tensile testing specimens were observed by OM and SEM. Therefore, Figure 11a) and c) present the GMAW joint fracture. The fracture was observed to happen in the upper part showing a transition mode to ductile fracture in the lower region. On the other hand, Figure 11b) and d) shows the friction weld sample fractured. Moreover, the fracture occurred in the HAZ region, while for friction welds the sample fractured in the base material. Still, an intense presence of dimples can be seen in Figure 11d). Hence, this weld quality was better than that observed in the GMAW joint.

\subsection{Bending test and its fracture}

The results for the bending tests of GMAW and friction welds are shown in Figure 12 and Figure 13, respectively. The samples were bent up to $180^{\circ}$ or until the appearance of visible defects. All the GMAW bended samples presented cracks in the weld region, even with a $60^{\circ}$ bent angle. This may be attributed to the large microstructural changes in the GMAW joints. For the other case, samples obtained by the friction process did not show any cracks, even for bending up to $180^{\circ}$ angle. This may be attributed to the large microstructural features which were displayed in GMAW joints. 
a)

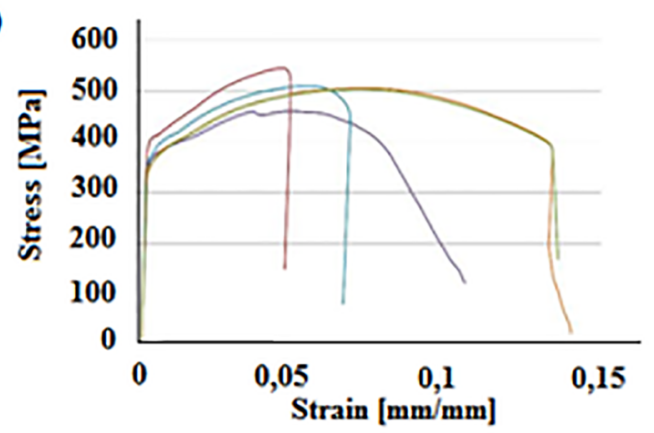

b)



Figure 10. Tensile testing curves: (a) GMAW joint (b) friction weld

Table 2. Average tensile testing results for GMAW and friction weld.

\begin{tabular}{lccc}
\hline Sample & Yeld Strength $(\boldsymbol{M P a})$ & Tensile Strength $(\mathbf{M P a})$ & elongation (\%) \\
\hline GMAW & 374,7 & 504,5 & 14,5 \\
Friction & 388,6 & 512,5 & 12,2 \\
\hline
\end{tabular}
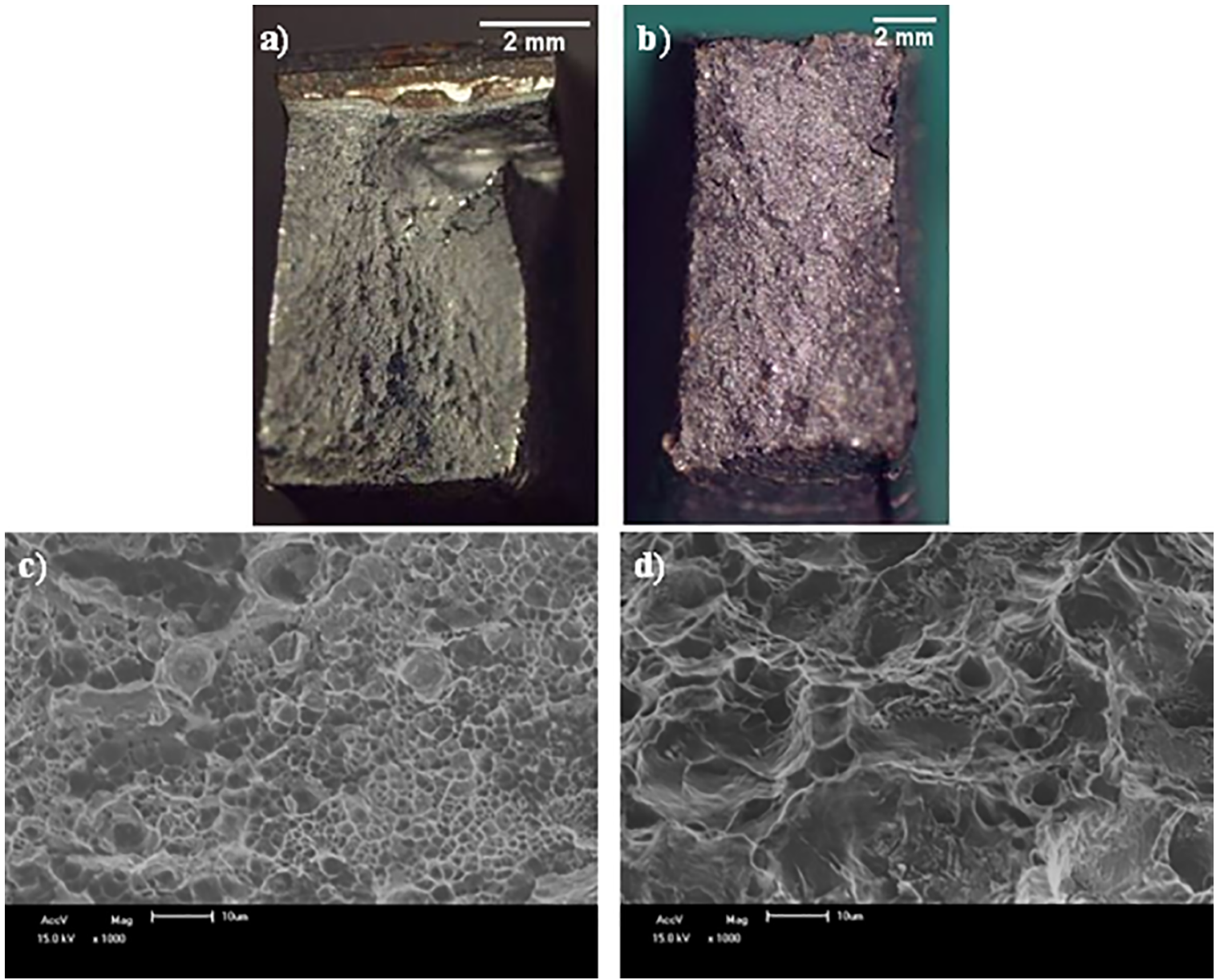

Figure 11. GMAW joint: (a) and (c); friction weld: (b) and (d) 


\begin{tabular}{|c|c|c|}
\hline Sample & $\begin{array}{c}\text { Bending } \\
\text { angle [ }\end{array}$ & Defects? \\
\hline GMAW 01 & 35 & Yes \\
\hline GMAW 02 & 46 & Yes \\
\hline GMAW 03 & 57 & Yes \\
\hline GMAW 04 & 6 & Yes \\
\hline GMAW 05 & 51 & Yes \\
\hline
\end{tabular}

Figure 12. Bending tests for GMAW joints

\begin{tabular}{|c|c|c|}
\hline Sample & $\begin{array}{c}\text { Bending } \\
\text { angle [\% }\end{array}$ & Defects? \\
\hline FRICTION01 & 180 & No \\
\hline FRICTION02 & 180 & No \\
\hline FRICTION03 & 180 & No \\
\hline FRICTION04 & 180 & No \\
\hline FRICTION05 & 180 & No \\
\hline
\end{tabular}

Figure 13. Bending tests for friction welds

\subsection{Hydrostatic test}

Hydrostatic tests were also performed in the welded joints. Their results are shown in Figure 14. For the GMAW joint (Figure 14a)), the maximum pressure achieved was 365 bar. In the other case, the friction weld reached around
450 bar (Figure 14b)). Accordingly, it was observed that the friction weld was more efficient, supporting higher pressures during longer test periods. For both processes, a sudden drop in pressure occurred due to the rupture of the weld seal system. The arrows indicate the leaking location during the hydrostatic testing (Figures 14a) and 14b)).
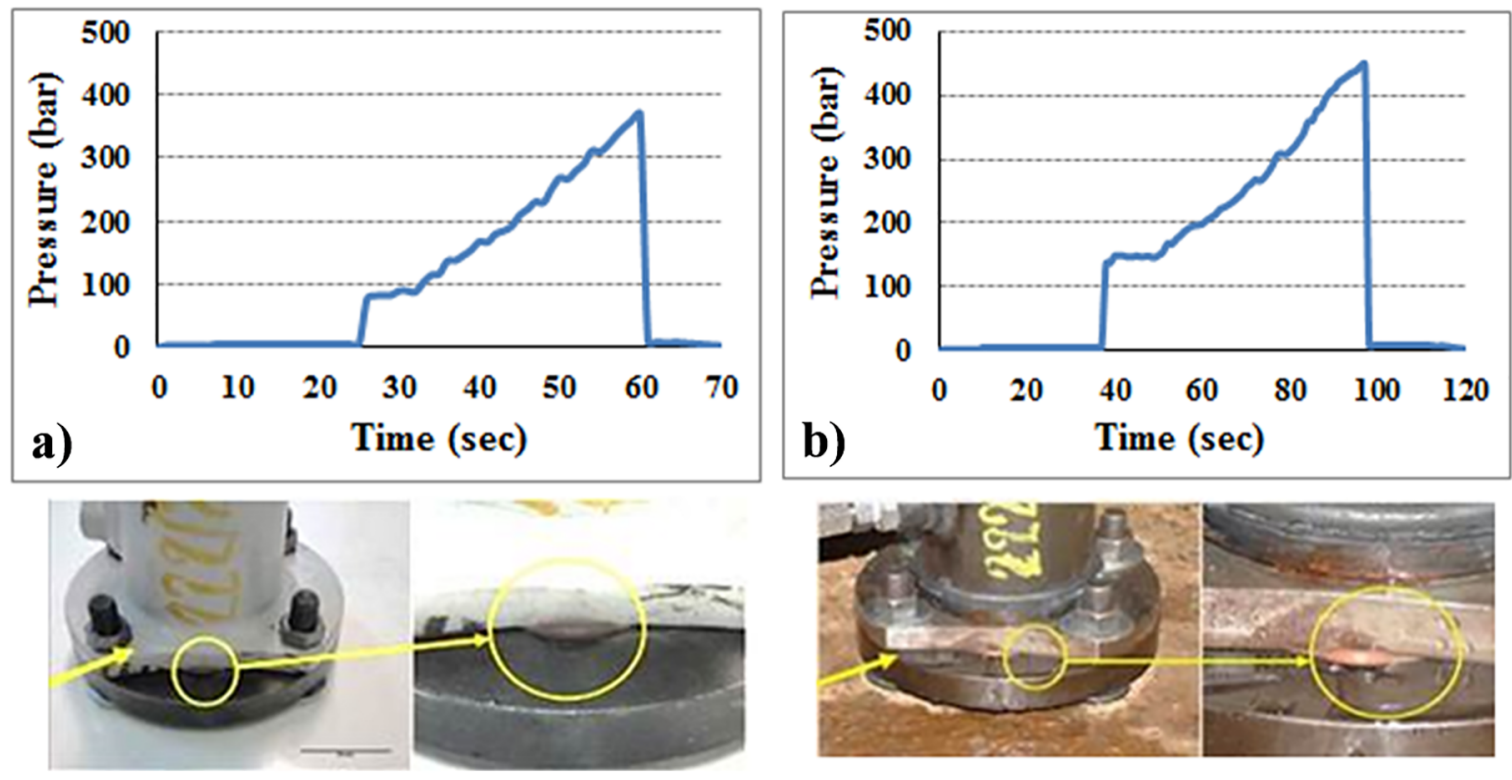

Figure 14. Hydrostatic test: (a) GMAW joint and (b) friction weld 


\section{Conclusions}

The replacement of the GMAW process by friction welding for joining tubes in the hydraulic cylinders industry was proven to be technically viable. The findings of the current investigation can be summarized as follow:

- A mixed weld microstructure was observed on the evaluated welds. However, the fusion welded part showed a heterogeneous solidified state. On the other hand, the friction welded joint presented a more homogeneous microstructure.

- Tensile tests indicated homogeneous mechanical properties for the friction welds studied. Otherwise, the GMAW joints showed a higher dispersion in the tensile testing results. This may be related to the microstructural heterogeneity of the GMAW joints. As an average, the friction weld UTS was greater.

- Bending tests presented a better performance for the friction welds when compared to the GMAW joints. In addition, the friction welded tubes showed no cracks even when the samples were bent up to a $180^{\circ}$ angle.

- The friction welded tube supported higher pressures. Nonetheless, both welds were approved in the hydrostatic tests.

\section{References}

1. Fernandes MT, Leão IF, Jácome PAD, Silva LM, Monteiro PCP. Caracterização das Microestruturas Obtidas por Meio de Ensaio Jominy Monitorado do Aço SAE 1026. Cadernos Unifoa. 2014;9(24):15-23.

2. Kursun T. Effect of the GMAW and GMAW-P Welding Processes on Microstructure, Hardness, Tensile and Impact Strength of AISI 1030 Steel Joint Fabricated by ASP316L Austenitic Stainless Steel Filler Metal. Archives of Metallurgy and Materials. 2011;56(4):955-964.

3. Çam G. Friction stir welded structural materials: beyond Alalloys. International Materials Reviews. 2011;56(1):1-48.

4. Mishra RS, Ma ZY. Friction stir welding and processing. Materials Science and Engineering: R: Reports. 2005;50(12):1-78.

5. Nandan R, DebRoy T, Bhadeshia HKDH. Recent advances in friction-stir welding - process, weldment structure and properties. Progress in Materials Science. 2008;53(6):980-1023.

6. Pradeep A. A Review on Friction Stir Welding of Steel. International Journal of Engineering Research and Development. 2012;3(11):75-91.

7. Buschinelli AJA, Niño CE. TRINCAS A FRIO INDUZIDAS PELO HIDROGÊNIO- métodos para determinação do préaquecimento. Available from: http://ftp.demec.ufpr.br/disciplinas/ EME733/Arquivos\%20da\%20disciplina/Buschinelli\%20-\%20 Trinca $\% 20$ Frio $\% 20 \mathrm{~m}$ todos $\% 20$ para $\% 20$ determina_o $\% 20$ do\%20pr_-aquecimento.pdf $>$. Access in: 04/05/2018.
8. Lemos GVB, Cunha PHCP, Nunes RM, Bergmann L, dos Santos JF, Clarke T. Residual stress and microstructural features of friction-stir-welded GL E36 shipbuilding steel. Materials Science and Technology. 2018;34(1):95-103. DOI: 10.1080/02670836.2017.1361148

9. Hanke S, Staron P, Fischer T, Fitseva V, dos Santos JF. A method for the in-situ study of solid-state joining techniques using synchrotron radiation - observation of phase transformations in Ti-6Al-4V after friction surfacing. Surface and Coatings Technology. 2018;335:355-367.

10. Lemos GVB, Nunes RM, Doll P, Bergmann L, Strohaecker T, dos Santos JF. Avaliação das Tensões Residuais em Juntas Soldadas de Inconel 625 Obtidas Através da Soldagem por Fricção e Mistura Mecânica. Soldagem \& Inspeção. 2017;22(1):35-45. DOI: $10.1590 / 0104-9224 /$ si2201.05

11. Hanke S, Lemos GVB, Bergmann L, dos Santos JF, Strohaecker TR. Degradation mechanisms of pcBN tool material during Friction Stir Welding of Ni-base alloy 625. Wear. 2017;376377(Pt A):403-408. DOI: 10.1016/j.wear.2017.01.070

12. Mattei F. Desenvolvimento de equipamento para estudo de soldagem por fricção. [Dissertation]. Porto Alegre: Universidade Federal do Rio Grande do Sul; 2011.

13. Cogo G. Processamento de pinos por atrito: Avaliação de características mecânicas e metalúrgicas de aços estruturais unidos pelo processo FTPW (Friction Taper Welding). [Graduation Completion Work]. Porto Alegre: Universidade Federal do Rio Grande do Sul; 2011.

14. Lemos GVB, Hanke S, dos Santos JF, Bergmann L, Reguly A, Strohaecker TR. Progress in friction stir welding of Ni alloys. Science and Technology of Welding and Joining. 2017;22(8):643657. DOI: 10.1080/13621718.2017.1288953

15. ASTM International. ASTM E384-11 - Standard Test Method for Microindentation Hardness of Materials. West Conshohocken: ASTM International; 2011.

16. ASTM International. ASTM E8/E8M-13 - Standard Test Methods for Tension Testing of Metallic Materials. West Conshohocken: ASTM International; 2013.

17. International Organization for Standardization (ISO). ISO7438:2016 - Metallic materials - Bend test. Geneva: ISO; 2016.

18. National Fluid Power Association (NFPA). NFPA-T2.6.1 R2-2000. Fluid Power Components - Method for Verifying the Fatigue and Establishing the Burst Pressure Ratings of the Pressure Containing Envelope of a Metal Fluid Power Accumulator. Milwaukee: NFPA; 2000.

19. Modenesi PJ, Marques PV, Santos DB. Introdução à metalurgia da soldagem. Belo Horizonte: Departamento de Engenharia Metalúrgica e de Materiais - UFMG; 2004.

20. Fattahi M, Nabhani N, Hosseini M, Arabian N, Rahimi E. Effect of Ti-containing inclusions on the nucleation of acicular ferrite and mechanical properties of multipass weld metals. Micron. 2013;45:107-114. 